\title{
The Experience of Sexual Coercion Among Young People in Kenya
}

By Annabel S. Erulkar

Annabel S. Erulkar is program associate, Population Council, Accra, Ghana.

CONTEXT: Studies of sexual behavior among young people in the developing world have generally neglected the circumstances in which sex takes place, most often assuming that when young people have sex, it is wanted and consensual. The few published studies on nonconsensual sex have often used highly selective samples, ignoring the experience of males and of married young people.

METHODS: A 2001 population-based survey of young people in Nyeri, Kenya, included a special module on sexual coercion. Descriptive data and multivariate analysis are used to explore the prevalence and patterns of sexual coercion among married and unmarried males and females aged 10-24.

RESULTS: Among the sexually experienced respondents, $21 \%$ of females and $11 \%$ of males had experienced sex under coercive conditions. Most of the perpetrators were intimate partners, including boyfriends, girlfriends and husbands. In a multivariate logistic regression, females who had ever been married and those who did not live with a parent or spouse had a significantly elevated risk of sexual coercion (odds ratios, 2.6 and 3.1, respectively); sexual coercion was associated with having had multiple sexual partners and with having had a reproductive tract infection (2.2 and 2.5). Males who had been coerced into sex were significantly more likely than those who had not to have had a first partner who was older by at least five years (82.9).

CONCLUSION: Reproductive health programs for young people need to address nonconsensual sex, including the special needs of males and of married females.

International Family Planning Perspectives, 2004, 30(4):182-189

The sexual behavior and reproductive health of young people in developing countries have attracted considerable attention over the last 15 years; youth constitute a large proportion of the population in these countries and are disproportionately affected by HIV and other negative reproductive health outcomes. ${ }^{1}$ The existing literature documents that adolescents engage in premarital sex with insufficient knowledge of reproduction and family planning, and that small proportions use contraceptives, especially condoms. ${ }^{2}$ Unfortunately, such studies have paid little attention to the social context of adolescent sexual activityparticularly the influence that gender relations and power imbalances have on whether and when young people have sex. Moreover, most of these studies have assumed that sex among young people is wanted and consensual. Evidence is emerging, however, that a sizeable proportion of episodes of sex among youth may result from coercion.

\section{BACKGROUND}

Sexual coercion refers to a range of experiences that compel a person to have sex against her or his will. ${ }^{3}$ These experiences include the use of "violence, threats, verbal insistence, deception, cultural expectations or economic circumstances"; the consequence is a "lack of choice to pursue other options without severe social or physical consequences." 4

The dearth of research on the experience of sexual coercion among young people is due, in part, to limited aware- ness, stigma, methodological constraints and ethical issues. Most of the existing research has been conducted among college-age women in developed countries. Eight percent of young women in a Canadian study and 15\% of those in a U.S. study reported having been physically forced to have sex..$^{5}$ In a nationally representative study of 1,121 U.S. youths aged 18-22 conducted in 1987, 7\% reported ever having been forced to have sex, with the highest rates among white females, of whom 13\% reported having had such an experience before age $20 .{ }^{6}$ Moreover, $9 \%$ of women aged 15-24 participating in the 1995 National Survey of Family Growth, a nationally representative U.S. study, reported that their first intercourse had not been voluntary. ${ }^{7}$

Studies have also examined long-term negative consequences of sexual coercion. Compared with young women who have not been sexually abused, those who have been abused tend to have more sex partners, ${ }^{8}$ as well as to have less control over the terms of sex, a lower likelihood of practicing family planning and using condoms; and a higher likelihood of experiencing sexually transmitted infections (STIs) and unwanted pregnancy. ${ }^{9}$ Long-term psychological consequences of early sexual abuse include depression, thoughts about suicide, negative self-esteem and lowered self-efficacy, drug addiction and alcoholism. ${ }^{10} \mathrm{~A}$ study in the U.S. state of Washington found high rates of sexual abuse among ever-pregnant teenagers. ${ }^{11}$ In addition, young women in the study who had been abused experienced sex- 
ual debut nearly two and a half years earlier than young women in the general population.

Over the past decade, a number of studies have demonstrated the difficulty of eliciting reliable reports of sexual coercion. ${ }^{12}$ Moreover, underreporting of sexual coercion among adolescents is likely to be compounded by underreporting of sexual intercourse. ${ }^{13}$ Premarital sex among young women is such a sensitive issue in many countries that accurate reporting is unlikely. ${ }^{14}$ In contrast, young men in many cultures may exaggerate their sexual experience because it is seen as a mark of manhood. ${ }^{15}$

The reporting of coerced sex in surveys may be even more problematic: Fear of retaliation, social stigma and lack of social support are often cited as barriers. ${ }^{16}$ Moreover, abused women may be less likely to participate in studies and lack rapport with interviewers. ${ }^{17}$

A comparison of three Nicaraguan surveys concluded that the reporting of violence improved when respondents were given several opportunities to disclose abuse, when the survey focused on violence and when the interviewer asked specific behavioral questions rather than general ones, such as "Have you ever been abused?"18 Although asking behaviorally specific questions may improve reporting, the means of sexual coercion are likely to vary across cultural settings. Therefore, defining exactly what behaviors to probe for in the context of large surveys of abuse poses additional challenges to the researcher, particularly those working in regions where few coercion studies have been conducted.

\section{Sexual Coercion of African Young People}

One of the earliest surveys that revealed the extent of coercion of youth in Sub-Saharan Africa was conducted in 1993 among 10,000 female secondary school students in Kenya. ${ }^{19}$ In this study, $24 \%$ of sexually experienced females reported that they had been forced into their first encounter. Moreover, in a study of contraceptive use among Kenyan high school students, $9 \%$ of sexually experienced young women explained that they had not used contraceptives the last time they had intercourse because they had been forced to have sex. ${ }^{20}$ More recently, studies in Ghana and Zimbabwe have found that sexual coercion is an important factor in sexual initiation and subsequent intercourse. In Ghana, 25\% of females aged 12-24 reported that their first intercourse had been forced; ${ }^{21}$ the respective figures in Zimbabwe were 12\% in an urban study and 33\% in a rural setting. ${ }^{22}$ All of these studies were based on large surveys that included sexual coercion as a minor component or a single question, rather than as the primary focus of the research. Little attention was paid to methodological issues, such as how questions on nonconsensual sex were asked, and none of the studies went beyond basic prevalence estimates to examine the experience of sexual coercion among young people.

Much of the published research focusing on sexual coercion among African adolescents has been qualitative, and many of studies have been conducted in South Africa. The South African studies, in particular, reveal a high frequency of violence in the context of intimate partner relation- ships, which is often attributed to the country's recent political and social transition. ${ }^{23}$ Pregnant young women in a study in Cape Town reported that partners used violence to initiate sexual relationships and physical assault to maintain them. ${ }^{24}$ In a clinic-based study to assess sexual decision-making in Durban, young women reported that fear of violence was one major reason for not discussing AIDS and for not using condoms. ${ }^{25}$ In this study, young women reported that refusing to have sex with their boyfriends nearly always resulted in forced sex.

Few studies have sought to understand the perceptions and meanings of coerced sex among African adolescents. One study in Nigeria used the narrative research method with secondary school students and youth in apprenticeship programs to explore the meaning and nature of coerced sex. ${ }^{26}$ Participants described coercive behavior as threatening or forcing someone into sex, engaging in unwanted touching, verbal abuse, deceiving someone into sex through forced exposure to pornography or the use of traditional charms, or not taking no for an answer. Females most often described perpetrators as males they knew, and males generally viewed females as naive, and therefore vulnerable to coercion.

One study in Cape Town investigated the relationship between teenage pregnancy and the experience of coercion. ${ }^{27}$ In that study, pregnant teenagers were significantly more likely than never-pregnant teenagers to have older partners and to have experienced forced sex. Similarly, 32\% of pregnant teenagers reported that their sexual initiation had resulted from rape or force, compared with 18\% of never-pregnant teenagers. Study respondents made a distinction between rape (physical coercion by strangers or relatives) and forced sex (physical coercion by a boyfriend). This finding adds additional ambiguities to the measurement of coerced sex.

Research on adolescents' experience of sexual coercion in Sub-Saharan Africa is much less developed than in the West; coercion is a new area for researchers in developing countries, there have been few opportunities for studies based on representative samples, and measurement of sexual coercion has not evolved. Many of the studies have used selective samples, such as pregnant teenagers, students or clinic patients, resulting in findings that are not generalizable to the entire population of adolescents. For example, rates of coercion from studies of pregnant teenagers are generally higher than those from representative samples of adolescents. Males' experiences of sexual coercion have been virtually ignored by developing country research, ${ }^{28}$ and practically all adolescent sexual behavior studies in SubSaharan Africa have included only the unmarried, neglecting the sizeable proportion of young women on the continent who marry during adolescence. Other studies have used ambiguous wording in questions about nonconsensual sex. For example, asking respondents whether they have been "forced" to have sex raises the possibility that respondents interpret the question as figurative force or compulsion, rather than literal physical force. 


\begin{tabular}{|c|c|c|}
\hline Characteristic & $\begin{array}{l}\text { Males } \\
(\mathrm{N}=754)\end{array}$ & $\begin{array}{l}\text { Females } \\
(\mathrm{N}=999)\end{array}$ \\
\hline \multicolumn{3}{|l|}{ Age $^{* * *}$} \\
\hline $10-14$ & 36.2 & 28.0 \\
\hline $15-19$ & 30.6 & 26.2 \\
\hline $20-24$ & 33.2 & 45.7 \\
\hline \multicolumn{3}{|l|}{ Ethnicity** } \\
\hline Kikuyu & 93.7 & 88.9 \\
\hline Non-Kikuyu & 6.3 & 11.1 \\
\hline \multicolumn{3}{|l|}{ Religion* } \\
\hline Catholic & 43.0 & 36.9 \\
\hline Other Christian & 53.4 & 59.2 \\
\hline Other non-Christian & 3.6 & 3.9 \\
\hline \multicolumn{3}{|l|}{ Education } \\
\hline None & 1.2 & 1.0 \\
\hline$<9 \mathrm{yrs}$ & 67.2 & 66.1 \\
\hline$\geq 9 \mathrm{yrs}$ & 31.6 & 32.9 \\
\hline \multicolumn{3}{|c|}{ Currently attending school*** } \\
\hline Yes & 51.1 & 35.6 \\
\hline No & 48.9 & 64.4 \\
\hline \multicolumn{3}{|l|}{ Marital status*** } \\
\hline Never-married & 94.3 & 69.8 \\
\hline Ever-married & 5.7 & 30.2 \\
\hline \multicolumn{3}{|c|}{ Socioeconomic status } \\
\hline Low (score, 0-4) & 29.4 & 31.4 \\
\hline High (score, 5-10) & 70.6 & 68.6 \\
\hline \multicolumn{3}{|c|}{ Sexually experienced } \\
\hline Yes & 44.7 & 46.2 \\
\hline No & 55.3 & 53.8 \\
\hline Total & 100.0 & 100.0 \\
\hline
\end{tabular}

This is one of the first large studies to focus on the prevalence, context and consequences of sexual coercion among young women and men in Sub-Saharan Africa. In contrast to most previous studies on the continent, it draws from a representative, population-based sample that includes married adolescents. Finally, the study recognizes that young men also experience coerced sex and includes their experiences. The study pays special attention to the measurement of sexual coercion, taking into account the methodological recommendations arising from previous studies of gender-based violence.

\section{METHODOLOGY}

Data

Data for this study were drawn from a large populationbased survey conducted in 2001 in Central Province, Kenya. The survey was carried out as part of a research project assessing the effect of an innovative reproductive health intervention for young people in the region.

In the initial stages of the study, all households were listed in a house-to-house survey. Households with young peo- ple aged 10-26 were selected for inclusion using a random number generator available in SPSS. To control for potential intrahousehold correlation, we used a Kish grid to randomly select one young person if a household had two or more who were eligible to be interviewed. Interviewers paid a maximum of three visits to the household to locate the selected respondent. In all, 2,712 married and unmarried young people were interviewed; for this analysis, however, we limited the sample to 10-24-year-olds to make it comparable to samples in other studies, and used data only from respondents living in Nyeri District. The overall response rate of the survey was $90 \%$, with a $92 \%$ response rate for females and an 86\% response rate for males.

A special module on sexual coercion was included in the survey. The module drew on the definition proposed by Heise and colleagues ${ }^{29}$ as well as on previous research in Kenya that described sex taking place as a result of deception or trickery, physical force or entrapment. ${ }^{30}$ Among the Kikuyu, especially those living in rural areas, young men who have just been circumcised often build their own dwelling or room separate from their parents' house. Earlier qualitative research has revealed that such rooms are frequently the location for sex, especially as newly circumcised males are often under pressure to have sex. ${ }^{31}$ Young women have reported being trapped in these rooms, while young men have reporting locking young women in. ${ }^{32}$ The introduction to the question was worded specifically to make respondents feel that they were not being singled out and that such occurrences are not uncommon: "I will read a list of experiences that adolescent males and females may have as they grow up...." Following the recommendations of Ellsberg and colleagues, ${ }^{33}$ we used behaviorally specific questions on coercion: Has anyone ever tricked you into having sex? Has anyone ever threatened you to make you have sex? Has anyone ever insisted on having sex with you, or not taken no for an answer? Has anyone ever locked you in a room to make you have sex? Has anyone ever physically forced you to have sex? Has anyone ever raped you?

Respondents who reported any of these experiences were asked follow-up questions on the number of times they had had the experience, the identity of the perpetrator, the age of the perpetrator, and whether they had reported the event. Because previous studies have shown that respondents reporting coerced sex may distinguish between "physically forced sex" and "rape," we asked about both. ${ }^{34}$ This study included only coercive acts that resulted in sexual intercourse; it did not measure attempts that were unsuccessful or forms of sex other than intercourse. The questionnaire was translated into both Kiswahili and Kikuyu by teams brought together for that purpose. Teams worked to achieve accurate translations of difficult terms, including descriptions used when exact translation was not possible.*

*The questionnaire was administered in Kikuyu for $57 \%$ of survey respondents. The word "threatened" in the question "Has anyone ever threatened you to make you have sex?" did not have a direct Kikuyu translation. Hence, the translated question most closely corresponds to "Has anyone ever blackmailed you or said that they would harm or hurt you in any way, to make you have sex?" 
The safety of respondents and the confidentiality of the information they provided were emphasized during the study. Informed consent was obtained from respondents and from the parents or guardians of respondents younger than 18. The survey, which solicited information on a broad range of topics-including time use, education, work, marriage, sexual behavior and reproductive health knowledgewas described to parents as a study of adolescents' experiences. The interviewers' training stressed that confidentiality was crucial and that violation of confidentiality was grounds for dismissal. To that end, the study protocol mandated that all interviews take place in a private place and that no one but the interviewer and the respondent be present during the interview.

During the introduction to the interview, respondents were told that they could skip any questions they did not wish to answer. At the end of the interview, they were given the opportunity to make comments or ask questions of the interviewer. If respondents needed assistance, interviewers gave them the names and contact information of the youth officer at a reproductive health agency and a local counselor who specialized in working with adolescents.

All analysis was stratified by sex to show how the circumstances of sexual coercion differ for males and females. First, descriptive analysis was used to characterize young people's experiences of coerced sex. Logistic regression was then used to explore factors associated with the experience of sexual coercion among sexually experienced young people.

\section{Variables}

Lifetime experience of sexual coercion was measured by asking respondents if they had ever had sex that resulted from deception, insistence, threats, physical force or rape, or being locked in a room. * It is examined in relation to individual and household-level background factors and reproductive health outcomes.

Demographic variables-age, school status, level of education and marital status-were included in the analysis to identify the characteristics of young men and women who were at elevated risk of sexual coercion. A variable indicating whether the respondent was engaged in paid work was also included in the model.

Household-level variables included living arrangements and a measure of socioeconomic status. Parental presence in the household has been shown to be protective against a range of risk behaviors and experiences during adolescence, including risky sexual behavior. ${ }^{35}$ Because the sample included both married and unmarried adolescents, the living arrangement variable reflected whether respondents had a resident parent or lived with a spouse. Household economic status was measured by an aggregate score based on 10 household assets. Respondents were asked whether or not their household had tap water, a flush toilet, electricity, radio, television, refrigerator, bicycle, livestock, land, and a market stall or shop. Scores ranged from zero to 10 , with a mean score of 4.1. Because this survey took place in

\begin{tabular}{|c|c|c|}
\hline Type & $\begin{array}{l}\text { Males } \\
(\mathrm{N}=337)\end{array}$ & $\begin{array}{l}\text { Females } \\
(\mathrm{N}=462)\end{array}$ \\
\hline Any & 11.0 & 20.8 \\
\hline Deception/trickery & 6.0 & 11.9 \\
\hline Threats & 0.6 & 3.7 \\
\hline Insistence/not taking no for an answer & 4.2 & 7.6 \\
\hline Locked in a room & 1.5 & 3.0 \\
\hline Physical force & 1.2 & 5.0 \\
\hline Rape & 0.9 & 3.2 \\
\hline
\end{tabular}

Note: Respondents could indicate more than one type of coercion.

the context of a reproductive health intervention research project, a variable measuring exposure to the intervention was included, although the intervention paid no explicit attention to gender-based violence or sexual coercion.

Studies in other settings have suggested that young women who have been coerced experience earlier sexual debut than those who have not. ${ }^{36}$ In addition, sexual coercion has been associated with a host of negative reproductive health problems and behaviors, including a higher incidence of reproductive tract infections, multiple sex partners, early pregnancy, lower condom use, and drug and alcohol use. These measures were included in the model to ascertain whether young people's experience of coercion was associated with subsequent risk-taking behavior and negative reproductive health outcomes. Because STIs are difficult to measure through self-reports, respondents were asked about symptoms (pain, unusual discharge or burning) associated with STIs and other reproductive tract infections. The variable for multiple partners was a dichotomous measure dividing respondents who had had three or more cumulative sex partners from those who had had fewer. In this survey, use of condoms during last intercourse was the measure of current condom use.

\section{RESULTS}

After the exclusion of respondents who lived outside Nyeri and those aged 25 or 26 , the sample for our study consisted of 1,753 young men and women aged 10-24 (Table 1). The female sample was slightly older than the male sample, with a larger proportion aged 20 or older. Educational levels in the region were relatively high: Virtually all respondents had been to school, with roughly one-third having reached the secondary level. There was no significant difference in educational attainment between males and females. The proportion in school was higher among males than among females, probably reflecting age differences between the male and female samples. Fewer than $6 \%$ of males had been married, compared with 30\% of females. Sexually experienced respondents (337 males and 462 females), who made up almost half of the sample, were the focus of our analyses. Among the sexually experienced, $11 \%$ of males and $21 \%$

*The outcome measure was dichotomous, because dividing the outcome by specific forms of coercion would have resulted in too few cases for analysis. 


\begin{tabular}{|c|c|c|}
\hline Perpetrator & $\begin{array}{l}\text { Males } \\
(\mathrm{N}=37)\end{array}$ & $\begin{array}{l}\text { Females } \\
(\mathrm{N}=96)\end{array}$ \\
\hline Boyfriend/girlfriend & 62.2 & 51.0 \\
\hline Husband/wife & 5.4 & 28.1 \\
\hline Acquaintance* & 35.1 & 21.9 \\
\hline Stranger & 5.4 & 8.3 \\
\hline Teacher/employer/relative & 0.0 & 5.1 \\
\hline
\end{tabular}

*Includes friends, neighbors and classmates. Note: Respondents may have reported more than one perpetrator because they had experienced more than one incident of coerced sex.

of females had experienced at least one form of coercion (Table 2, page 185). Among young people who had been coerced, the majority reported having been deceived or tricked into having sex, and many reported partner insistence or "not taking no for an answer." In a finding consistent with previous research suggesting that respondents may consider forced sex different from rape, $5 \%$ of sexually experienced females reported having been physically forced into sex, and 3\% reported having been raped. Seventy-five percent of young women who reported rape also reported having been physically forced into having sex, possibly referring to the same event (not shown). However, only $48 \%$ of those who reported sex by physical force also reported rape, suggesting that the term rape had particular connotations for respondents. Indeed, young women who reported having been raped were more likely than those who reported physically forced sex to say that a stranger was the perpetrator.

For young women, intimate partners-boyfriends and husbands-were the most common perpetrators of sexual coercion, followed by acquaintances (Table 3). Of the coerced young women who were married, $45 \%$ had been coerced by their husbands, $33 \%$ by someone else and $22 \%$ by both their husband and someone else (not shown). Among males who had been coerced, the most common perpetrator was a girlfriend, followed by an acquaintance. Few respondents reported having been coerced by a relative, teacher or employer; this figure, however, is probably an underestimate, given the stigma attached to incest and the disapproval of intimate relationships between young people and their teachers or employers. Only 23\% of young women and $22 \%$ of young men who had been coerced told anyone about the experience (not shown). When they did tell someone, it was usually a family member or friend.

\begin{tabular}{|c|c|c|c|c|}
\hline \multirow[t]{2}{*}{ Characteristic } & \multicolumn{2}{|l|}{ Males } & \multicolumn{2}{|l|}{ Females } \\
\hline & $\begin{array}{l}\text { Never } \\
\text { coerced } \\
(\mathrm{N}=276)\end{array}$ & $\begin{array}{l}\text { Ever } \\
\text { coerced } \\
(\mathrm{N}=35)\end{array}$ & $\begin{array}{l}\text { Never } \\
\text { coerced } \\
(\mathrm{N}=357)\end{array}$ & $\begin{array}{l}\text { Ever } \\
\text { coerced } \\
(\mathrm{N}=92)\end{array}$ \\
\hline 1st sex before age $15 \dagger$ & 23.2 & 34.3 & 9.8 & $17.4^{*}$ \\
\hline 1st partner $\geq 5$ yrs. older & 1.7 & $21.6^{* * *}$ & 46.0 & $56.2^{*}$ \\
\hline 1 st partner $\geq 10$ yrs. older & 0.3 & $5.4^{*}$ & 9.8 & 15.7 \\
\hline
\end{tabular}

\section{Respondents' Characteristics and Coercion}

Seventeen percent of young women who had ever been coerced had had sex before age 15, compared with $10 \%$ of those who had not (Table 4). Among both genders, young people who had experienced coercion were significantly more likely than those who had not to have had first sex partners who were five or more years older than themselves. Some $22 \%$ of young men who had been coerced had had much older first partners, compared with fewer than $2 \%$ of their counterparts who had not been coerced. Fifty-six percent of young women who had experienced coercion had had first partners who were five or more years older, compared with $46 \%$ of other young women.

Multivariate logistic regression was used to identify the characteristics that differentiated sexually experienced young men and women who had experienced sexual coercion from those who had not (Table 5). With the exception of marital status, no individual-level demographic variables were associated with the experience of nonconsensual sex. Among young women, those who had ever been married had significantly elevated odds of having experienced sexual coercion (odds ratio, 2.6), a finding that suggests a high prevalence of coercion within marriage. However, separated and divorced women were more likely to have experienced coercion than currently married young women who were living with their husbands (4.7; not shown). Likewise, young women who lived alone were more likely than those who lived with at least one parent or a spouse to have experienced coercion (3.1).

For young women, nonconsensual sex was associated with negative reproductive health behavior and outcomes. Those who had been coerced were more likely to have had three or more cumulative sex partners and to have experienced symptoms of reproductive tract infection (2.2 and 2.5). Because condom use among young women did not differ significantly by whether they had been coerced into sex, it is likely that their more frequent reporting of symptoms resulted from a greater number of sex partners.

For young men, the experience of sexual coercion was associated with only one variable, having had a first sex partner who was five or more years older (82.9). Having a first partner who is much older is fairly common for young women in Africa. For young men, however, having a much older first partner is unusual and confers a much higher risk of coercive sex.

\section{DISCUSSION}

This study draws on a representative sample of married and unmarried young men and women aged 10-24 in Kenya to explore the prevalence and patterns of sexual coercion. Our findings reveal that nonconsensual sex is a common-and often overlooked-feature of the early sexual experiences of the country's young women and men. Contrary to the popular assumption that sex among young people is consensual, a substantial number of respondents in our sample had had sex when they did not want to. More than one in five sexually experienced young women and 


\begin{tabular}{|c|c|c|}
\hline Characteristic & $\begin{array}{l}\text { Males } \\
(\mathrm{N}=257)\end{array}$ & $\begin{array}{l}\text { Females } \\
(\mathrm{N}=368)\end{array}$ \\
\hline \multicolumn{3}{|l|}{ Demographic } \\
\hline Age & 0.95 & 0.93 \\
\hline Currently attending school & 0.50 & 0.97 \\
\hline \multicolumn{3}{|l|}{ Educational attainment } \\
\hline$<9$ yrs. & 1.00 & 1.00 \\
\hline$\geq 9$ yrs. & 1.34 & 1.52 \\
\hline Currently working for pay & 0.83 & 0.78 \\
\hline Ever married & 0.99 & $2.59^{*}$ \\
\hline Aware of $\mathrm{RH}$ intervention & 1.77 & 1.65 \\
\hline \multicolumn{3}{|l|}{ Household } \\
\hline \multicolumn{3}{|l|}{ Household economic index } \\
\hline Low & 1.00 & 1.00 \\
\hline High & 1.09 & 1.04 \\
\hline \multicolumn{3}{|l|}{ Living arrangements } \\
\hline Live with no parents or spouse & 1.61 & $3.09^{*}$ \\
\hline Live with parent(s) or spouse & 1.00 & 1.00 \\
\hline \multicolumn{3}{|c|}{ Sexual behavior/reproductive health } \\
\hline First sex before age 15 & 1.78 & 1.10 \\
\hline First partner $\geq 5$ yrs. older & $82.92^{* * *}$ & 1.26 \\
\hline Had $\geq 3$ cumulative sex partners & 1.53 & $2.16^{*}$ \\
\hline Has drunk alcohol & 2.15 & 1.45 \\
\hline Ever experienced RTI symptoms & 2.60 & $2.50^{*}$ \\
\hline Used condom at last sex & 0.54 & 0.67 \\
\hline Ever pregnant & na & 0.51 \\
\hline $\begin{array}{l}-2 \text { log likelihood } \\
R^{2}\end{array}$ & $\begin{array}{l}157.40 \\
246\end{array}$ & 338.38 \\
\hline
\end{tabular}

one in 10 sexually experienced young men had had nonconsensual sex. The perpetrators were often the young people's intimate partners-their boyfriends, girlfriends and husbands.

Young men whose first partner had been five or more years older had a higher risk of sexual coercion than did other young men. Ever-married young women were more likely than their never-married counterparts to report coercion, and their husbands were often the perpetrators. Those who reported coercion had elevated odds of being separated or divorced, suggesting that coercion may have contributed to marriage dissolution. Thus, although it is commonly assumed that marriage is a safe refuge for young women; ${ }^{37}$ our results suggest that marriage may increase the risk of sexual violence, and other research indicates that it may increase a young woman's risk of HIV infection. ${ }^{38}$ Young women who are coerced into sex by their husbands may have fewer options than unmarried women to protect themselves against infection, may find it harder to leave an abusive relationship and may not have recourse to legal protection. In Kenya generally, as well as among the Kikuyu traditionally, husbands cannot be accused of raping their wives because marriage is considered as blanket consent to intercourse. ${ }^{39}$

Under Kenya's penal code, rape, attempted rape and other forms of nonconsensual sex are crimes punishable by imprisonment. ${ }^{40}$ In practice, however, the law is rarely enforced, and society tends to blame rather than support the victim, which discourages reporting. ${ }^{41}$ Moreover, rape is often looked on as a normal and forgivable action by males who cannot control themselves. For example, when 19 secondary schoolgirls were killed and 71 others were raped in 1991 by male students in their dormitory at St. Kizito in Meru, Kenya, the deputy principal at the school was quoted as saying, "The boys never meant any harm against the girls. They just wanted to rape." 42

Compared with young women who have never experienced coercion, those who have are at higher risk of reproductive tract infections and are more likely to have had multiple sexual partners. African programs for young people, which tend to emphasize abstinence, usually overlook early experiences of violence and coerced sex. The message in these programs, which is often directed at young women, advises them to "just say no" to young men's advances. However, as our study shows, many young women do not have a choice on whether to have sex. Moreover, many of risky behaviors programs are attempting to combat are associated with early experiences of abuse. Addressing sexual violence in programs will not only respond to the contextual realities of many young women and men, but will help to prevent long-term negative reproductive health outcomes that result from violence.

By failing to addressing nonconsensual sex and genderbased violence, reproductive health programs for young people are also missing an important opportunity to change the community perception that these experiences are the victim's fault. Program staff have ongoing contact with young people and often broach sensitive topics such as sexuality. In addition, many enjoy high status in their communities, either because of their affiliation with the program or because they are teachers, respected community leaders or health care workers. Because of this stature, program staff are well-placed to break the silence and challenge the misconceptions associated with violence, as well as to promote systems that support and protect victims and punish offenders. Finally, married young women, a large but vulnerable population, need a prominent place in adolescent policies and programs, with recognition of the risks they face in marriage and their right to protection.

\section{REFERENCES}

1. MacCauley AP and Salter C, Meeting the needs of young adults, Population Reports, 1995, Series J, No. 41.

2. Ajayi A et al., Adolescent sexuality and fertility in Kenya: a survey of knowledge, perceptions and practices, Studies in Family Planning, 1991, 22(4):205-216; Amazigo U et al., Sexual activity and contraceptive knowledge and use among in-school adolescents in Nigeria, International Family Planning Perspectives, 1997, 23(1):28-33; Boohene E et al., Fertility and contraceptive use among young adults in Harare, Zimbabwe, Studies in Family Planning, 1991, 22(4):264-271; Gorgen R, Sexual behavior and attitudes among unmarried youth in Guinea, International Family Planning Perspectives, 1998, 24(2):65-71; Kiragu K and Zabin L, Contraceptive use among high school students in Kenya, International Family Planning Perspectives, 1993, 21(3):108-113; and Rwenge M, Sexual risk behaviors among young people in Bamenda, Cameroon, International Family Planning Perspectives, 2000, 26(3):118-123.

3. Heise L, Ellsberg M and Gottemoeller M, Ending violence against women, Population Reports, 1999, Series L, No. 11. 
4. Heise L, Moore K and Toubia N, Sexual coercion and reproductive health: a focus on research, New York: Population Council, 1995.

5. Heise L, Pitanguy J and Germain A, Violence against women: the hidden health burden, Discussion Paper, Washington, DC: World Bank, 1994, No. 255

6. Moore KA, Nord CW and Peterson JL, Nonvoluntary sexual activity among adolescents, Family Planning Perspectives, 1989, 21(3):110-114

7. Abma J, Driscoll A and Moore K, Young women's degree of control over first intercourse: an exploratory analysis, Family Planning Perspectives, 1998, 30(1):12-18.

8. Ibid.

9. Ibid.; Boyer D and Fine D, Sexual abuse as a factor in adolescent pregnancy and child maltreatment, Family Planning Perspectives, 1992 24(1):4-11 \& 19; and United Nations Children's Fund (UNICEF), Domestic violence against women and girls, Florence, Italy: Innocenti Research Center, 2000

10. Boyer D and Fine D, 1992, op. cit. (see reference 9); UNICEF, 2000, op. cit. (see reference 9); Heise L, Ellsberg M and Gottemoeller M, 1999 op. cit. (see reference 3); and Heise L, Pitanguy J and Germain A, 1994, op. cit. (see reference 5).

11. Boyer D and Fine D, 1992, op. cit. (see reference 9).

12. Ellsberg M et al., Researching domestic violence against women: methodological and ethical considerations, Studies in Family Planning 2001, 32(1):1-16; UNICEF, 2000, op. cit. (see reference 9); Heise L, Ellsberg M and Gottemoeller M, 1999, op. cit. (see reference 3); and Heise L, Moore K and Toubia N, 1995, op. cit. (see reference 4).

13. Mensch B, Hewett $P$ and Erulkar AS, The reporting of sensitive behavior among adolescents: a methodological experiment in Kenya Demography, 2003, 40(2):247-268; and Singh S et al., Gender differences in the timing of first intercourse: data from 14 countries, International Family Planning Perspectives 2000, 26(1):21-28 \& 43.

14. Gage-Brandon A and Meekers D, Sex, contraception and childbearing before marriage in Sub-Saharan Africa, International Family Planning Perspectives, 1993, 19(1):14-18 \& 33.

15. Ibid.; and Boohene E et al., 1991, op. cit. (see reference 2).

16. Heise L, Moore K and Toubia N, 1995, op. cit. (see reference 4); and Heise L, Ellsberg M and Gottemoeller M, 1999, op. cit. (see reference 3).

17. Ellsberg M et al., 2001, op. cit. (see reference 12).

18. Ibid.

19. Youri P, ed., Female adolescent health and sexuality in Kenyan secondary schools: a survey report, Nairobi, Kenya: African Medical Research Foundation, 1994.

20. Kiragu K and Zabin L, 1993, op. cit. (see reference 2).

21. Glover EK et al., Sexual health experiences of adolescents in three Ghanaian towns, International Family Planning Perspectives, 2003, 29(1): $32-40$.

22. Phiri A and Erulkar A, Experiences of youth in urban Zimbabwe, Harare, Zimbabwe: Zimbabwe National Family Planning Council, 2000; and Phiri A and Erulkar A, Experiences of youth in rural Zimbabwe, Harare, Zimbabwe: Zimbabwe National Family Planning Council, 2000.

23. Maitse T, Political change, rape, and pornography in post-apartheid South Africa, Gender and Development, 1998, 6(3):55-59.

24. Wood K and Jewkes R, Violence, rape and sexual coercion: everyday love in a South African township, Gender and Development, 1997, 5(2):4l-46.

25. Varga C, Sexual decision-making and negotiations in the midst of AIDS: youth in KwaZulu-Natal, South Africa, Health Transition Review, 1997, 7(Suppl. 3):45-67.

26. Ademola A et al., Perceptions of sexual coercion: learning from young people in Ibadan, Nigeria, Reproductive Health Matters, 2001, 9(17):128136.

27. Jewkes R et al., Relationship dynamics and adolescent pregnancy in South Africa, Social Science \& Medicine, 2001, 52(5):733-744.
28. Jejeebhoy $S$ and Bott $S$, Non-consensual sexual experiences of young people: a review of evidence from developing countries, Working Paper, New Delhi: Population Council, 2003.

29. Heise L, Moore K and Toubia N, 1995, op. cit. (see reference 4).

30. Balmer DH, The Phenomenon of Adolescence: An Ethnographic Inquiry, Nairobi, Kenya: Network for AIDS Research in East and Southern Africa, 1994; Population Council, Unpublished transcripts of in-depth interviews among adolescents in Nyeri and Nakuru, Kenya, Nairobi, Kenya: Population Council, 1997; and Youri P, 1994, op. cit. (see reference 19).

31. Ellsberg M et al, 2001, op. cit. (see reference 12).

32. Ahlberg B et al., The Mwomboko Research Project: the practice of male circumcision in Central Kenya and its implications for the transmission and prevention of STD/HIV, African Sociological Review, 1997, 1(1):66-81; and Population Council, 1997, op. cit. (see reference 30).

33. Balmer DH, 1994, op. cit. (see reference 30); and Population Council, 1997, op. cit. (see reference 30).

34. Jewkes R et al., 2001, op. cit. (see reference 27).

35. Ngom P, Magadi MA and Owour T, Parental presence and adolescent reproductive health among the Nairobi urban poor, Journal of Adolescent Health, 2003, 33(5):369-377.

36. Boyer D and Fine D, 1992, op. cit. (see reference 9).

37. Bruce J and Clark S, The implications of early marriage for HIV/AIDS policy, New York: Population Council, 2004.

38. Glynn JR et al., 2001, Why do young women have a much higher prevalence of HIV than young men? a study in Kisumu, Kenya, and Ndola, Zambia, AIDS, 2001, 15(Suppl 4):S51-S60; and Bruce J and Clark S, 2004, op. cit. (see reference 37 ).

39. Kenyatta, J, Facing Mount Kenya: The Traditional Life of the Kikuyu, London: Martin, Secker and Warburg, 1938; and Center for Reproductive Law and Policy (CRLP) and International Federation of Women Lawyers, Women of the World: Laws and Policies Affecting Their Reproductive Lives: Anglophone Africa, New York: CRLP and International Federation of Women Lawyers, 1997.

40. CRLP and International Federation of Women Lawyers, 1997, op. cit. (see reference 39).

41. Balmer DH, 1994, op. cit. (see reference 30); and Jejeebhoy S and Bott S, 2003, op. cit. (see reference 28).

42. Perlez J, Kenyans do some soul-searching after the rape of 71 schoolgirls, New York Times, July 29, 1991.

43. Erulkar AS and Mensch BS, Youth centers in Kenya: evaluation of the Family Planning Association of Kenya Program, Nairobi, Kenya: Population Council, 1997.

\section{RESUMEN}

Contexto: Los estudios sobre la conducta sexual de los jóvenes en los países en desarrollo generalmente no dan importancia a las circunstancias en las cuales se mantiene una relación sexual, y en la mayoría de los casos se asumen que esa relación es deseada y consensual. Los pocos estudios publicados sobre sexo no consensual utilizan muestras sumamente selectivas y dejan de lado la experiencia de los hombres y los jóvenes casados.

Métodos: Una encuesta de 2001 con base en la población realizada a jóvenes de Nyeri, Kenya, incluyó un módulo especial sobre coerción sexual. Se utilizan datos descriptivos y análisis multivariados para examinar la prevalencia y las tendencias del sexo forzado entre hombres y mujeres casados y solteros, de entre 10 y 24 años.

Resultados: Entre los entrevistados sexualmente activos, el $21 \%$ de las mujeres y el $11 \%$ de los hombres indicaron haber tenido relaciones sexuales en condiciones de coerción. La mayoría de los perpetradores eran personas de su intimidad, 
inclusive novios, novias y cónyuges. Los resultados de un análisis de regresión logística multivariada indicaron que las mujeres casadas alguna vez, y aquellas que no vivían con sus padres o su cónyuge, presentaban un riesgo significativamente más elevado de sufrir coerción sexual (razones de momios de 2,6 y 3,1, respectivamente); el sexo forzado estuvo relacionado con haber tenido varias parejas sexuales y una infección del tracto reproductivo $(2,2$ y 2,5). Los hombres que habian sido objeto del sexo forzado eran mucho más proclives que otros hombres a haber tenido una primera pareja sexual que tenía por lo menos cinco años más edad que él $(82,9)$.

Conclusion: Los programas de salud reproductiva para jóvenes deben prestar atención al sexo no consensual, prestando especial atención a las necesidades particulares de los hombres $y$ de las mujeres casadas.

\section{RÉSUMÉ}

Contexte: Les études de comportement sexuel des jeunes du monde en développement négligent généralement les circonstances dans lesquelles interviennent les relations sexuelles, présumant le plus souvent que les rapports sexuels des jeunes sont voulus et consensuels. Les rares études publiées sur les rapports sexuels non consensuels reposent souvent sur des échantillons hautement sélectifs, omettant l'expérience des hommes et des jeunes mariées.

Méthodes: Une enquête en population générale menée en 2001 parmi les jeunes de Nyeri (Kenya) comportait un module spécial sur la contrainte sexuelle. Les données descriptives et l'analyse multivariée servent à explorer la prévalence et les profils de la contrainte sexuelle parmi les jeunes hommes et femmes mariés et célibataires de 10 à 24 ans.

Résultats: Parmi les répondants sexuellement expérimentés, $21 \%$ des femmes et $11 \%$ des hommes avaient connu des relations sexuelles sous contrainte. Les responsables en étaient pour la plupart des partenaires intimes: petits amis, petites amies et maris. Selon un modèle de régression logistique multivariée, les femmes mariées ou qui l'avaient jamais été et celles qui ne vivaient pas avec un parent ou un conjoint couraient un risque significativement élevé de contrainte sexuelle (rapports de probabilités, 2,6 et 3,1, respectivement). La contrainte sexuelle était du reste associée à la multiplicité des partenaires sexuels et au vécu d'une infection de l'appareil génital (2,2 et 2,5). Les hommes qui avaient subi une contrainte sexuelle étaient significativement plus susceptibles que les autres d'avoir eu pour première partenaire une femme d'au moins cinq ans leur aînée $(82,9)$.

Conclusion: Les programmes de santé reproductive destinés aux jeunes doivent faire face au problème des rapports sexuels non consensuels et considérer, notamment, les besoins spéciaux des hommes et des femmes mariées.

\section{Acknowledgments}

This research was supported by the Rockefeller Foundation and conducted in collaboration with the Family Planning Association of Kenya. The author thanks Ian Diamond, Zoë Mathews, John Cleland, Jane Falkingham, Pierre Ngom, Shireen Jejeebhoy and Ayo Ajayi for comments on earlier versions of the article.

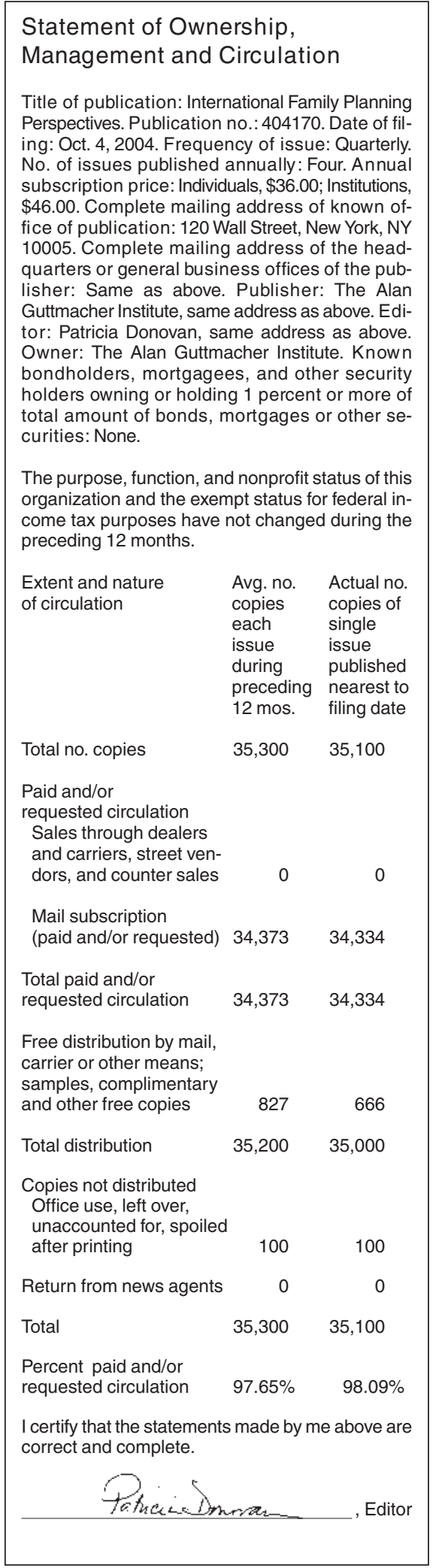

ing: Oct. 4,2004. Frequency of issue: Quarterly. No. of issues published annually: Four. Annua $\$ 46.00$. Complete mailing address of known of fice of publication: 120 Wall Street, New York, NY 10005. Complete mailing address of the heada Guttmacher Institute, same address as above. Editor: Patricia Donovan, same address as above. bondholders, mortgagees, and other security holders owning or holding 1 percent or more of total amount of bonds, mortgages or other sepreceding 12 months.

Author contact:aerulkar@pcaccra.org 